\title{
"LIKE GIVING A WHEELCHAIR TO SOMEONE WHO SHOULD BE WALKING" \\ Interpreter access and the problematisation of linguistic diversity in the justice system
}

\author{
Joseph MacFarlane, Ceyhan Sirma Kurt, \\ Georgina Heydon \& Andy Roh
}

\section{Introduction}

While Australian society claims to celebrate and value cultural diversity, the same cannot always be said about the country's approach to non-English languages. With over 300 languages spoken, including more than 100 indigenous languages, public institutions are faced with the challenge of recognising and catering for linguistic diversity in practice. A key approach for addressing this is the enhanced provision of interpreters. While improvements have been made for many government services, a notable exception is in the justice system where, in legal settings, the provision of interpreters remains inadequate, both in terms of quantity and quality. Furthermore, the discretionary use of interpreters means that, even where qualified interpreters are available, they can still be underused in practice. Both problems are indicative of an ideology which both privileges English monolingualism and suppresses the language practices and preferences of minority language speakers. In this chapter, we address the practical concerns that this ideological position gives rise to, with the aim of promoting an orientation that views linguistic diversity as a resource to be harnessed, rather than a "problem" to be overcome by imposing the normative standards of English monolingualism.

\section{National diversity}

Australia is seeing an increase in its linguistic diversity, with over 300 languages spoken, and $21 \%$ of the population primarily speaking a language other than English at home. Since 2011, the proportion of English monolingual speakers has decreased from 77\% to 73\%, indicating that multilingualism has also become an increasing part of Australian society, according to the Australian Bureau of Statistics (ABS, 2016a). Further to this, over 450000 people between the ages of 15 and 69 who speak a language other than English have also 
reported speaking English either not well or not at all (ABS, 2016b). While this represents only a small percentage of the population, it remains important to recognise that, for many, English is not always the preferred language through which to communicate. According to the second National Indigenous Languages Survey in 2014, 120 indigenous languages were still being spoken in Australia, a number which has decreased from 145 in 2005; and prior to the British invasion, over 250 traditional indigenous languages were spoken (Marmion, Obata \& Troy, 2018). The National Aboriginal and Torres Strait Islander Social Survey has also found that around 38\% of Aboriginal and Torres Strait Islander people over the age of 15 speak an indigenous language, with 11\% speaking an indigenous language at home (ABS, 2016b). Over 70\% of Aboriginal and Torres Strait Islander people living in remote communities speak an indigenous language (ABS, 2016b). While this is only a brief snapshot, it indicates that linguistic diversity remains a significant aspect of Australian society.

The increasing diversity of Australian society has been accompanied by political rhetoric that often claims to celebrate this diversity. This is exemplified in Australia's Multicultural Statement which depicts the country as a united, egalitarian society which "flourishes in part thanks to our cultural diversity" (2017:7). However, while cultural differences might be celebrated, linguistic diversity is a less welcome presence. The Statement makes a point of stressing that "English is and will remain our national language and is a critical tool for migrant integration" (2017:13), implying that not to speak English is not to integrate into Australian life. Furthermore, while the statement recognises that Australia has historically been a highly multilingual society, with over 250 indigenous languages and hundreds more dialects spoken before colonisation began in 1788, it also states that "modern" Australia was realised through British and Irish settlement (2017:7), which brought with it the introduction and imposition of English as the de facto national language (Marmion et al., 2014; Lo Bianco, 1987). Indeed, the deliberate suppression of indigenous languages has been well documented, with speakers sometimes facing physical punishment for using them (Human Rights and Equal Opportunity Commission, 1997; Lo Bianco, 1987). While Lo Bianco (1987) claims that Australia has sought to reverse its trend towards English monolingualism, its contemporary multicultural statement largely depicts English as the language of modernity, progress, opportunity and national unity. Furthermore, public spaces and major institutions are frequently built on an ideal of English monolingualism that renders them inaccessible to many (Piller, 2016). The high value afforded English in Australia is further reflected in an ongoing push to implement tougher English-language testing for newly arrived migrants in order for them to gain citizenship. As such, while the country might claim to tolerate limited amounts of linguistic diversity in private circles, efforts to enforce linguistic unification through English remain structurally embedded, especially in public domains. 


\section{Access to language services}

Given the hegemonic status of English in Australia, access to language services has become a necessity to mitigate the disadvantage that this creates for speakers of minority languages. This has typically come via the growth of interpreter services and accreditation bodies, for example, the National Translating and Interpreting Service (TIS National), initially established in 1973 and renamed the Emergency Telephone Interpreter Service; the 1977 founding of the National Accreditation Authority for Translators and Interpreters (NAATI); and the introduction of two government-funded indigenous interpreting services - the Northern Territory Aboriginal Interpreter Service, in 2000, and Western Australia's Kimberley Interpreting Service (also established in 2000 and now named Aboriginal Interpreting WA). Given this expansion, many clients from a Non-English Speaking Background (NESB), or who speak English as an additional language (EAL speakers), have been given greater access to interpreting services to the point where they are often available by request in many public service encounters. This trend in state and federal policies is further reflected in annual reports released by the Access and Equity committee and NAATI (Access and Equity Inquiry Panel, 2012; NAATI, 2016), in which the former mainly stresses increasing "responsiveness" of public services, while the latter presents a statistical increase in demand for accredited language professionals each year.

\section{Exclusion and inadequate services in the justice system}

However, a notable exception to the availability and effective use of interpreters is in the justice system. This has long been recognised as a concern with the 1992 report of the Australian Law Reform Commission (ALRC), Multiculturalism and the Law, indicating that the justice system suffered from an underuse and under-availability of on-site legal interpreters for people whose first language was not English. While this report focused specifically on Culturally and Linguistically Diverse (CALD) communities in Australia, multiple reviews have also found that the inadequate number of interpreter services for often excludes Aboriginal and Torres Strait Islander people who primarily speak an indigenous language. Illustrative of this is that a year prior to the ALRC review, the 1991 Royal Commission into Aboriginal Deaths in Custody (RCIADIC) had found that indigenous language speakers were being denied legitimate participation in legal matters that affected them because of the absence of interpreters. Almost 30 years later, and the ALRC's (2017) Pathways to Justice report echoed the criticisms of the RCIADIC by suggesting that a shortage of properly trained indigenous interpreters was contributing to the stark overrepresentation of Aboriginal and Torres Strait Islander people being held in custody. This is largely because the absence of interpreters can prolong a person's stay in custody if their hearing cannot be fairly conducted in English. Ultimately, this means that, in one of Australia's major institutions, the imposition of a dominant language, combined 
with the inadequate use and provision of interpreters, continues to marginalise people who predominantly speak a minority language, and devalues their linguistic repertoires. The repeated failure to provide legally-trained, high quality interpreter services for indigenous language speakers, as well as non-indigenous non-English speakers, continues to exclude many from any kind of meaningful participation in the legal process.

It is especially important to recognise that the underuse and under-provision of indigenous language interpreters is especially critical in the justice system. Whereas Aboriginal and Torres Strait Islander people constitute only $2 \%$ of the country's total population, they comprise around $27 \%$ of the prison population (ABS, 2017a). In the Northern Territory, where over 100 Aboriginal languages and dialects are spoken, Aboriginal people constitute $84 \%$ of the adult prison population (ABS, 2017b) and are 13 times more likely to be incarcerated than non-indigenous people. In Western Australia, Aboriginal people are 15 times more likely to be incarcerated than non-indigenous people (ABS, 2017c). Unfortunately no data are publicly available regarding the languages spoken by these populations, or even how frequently interpreters are used, but it is reasonable to assume that many who find themselves in contact with the justice system, particularly in the Northern Territory, speak an indigenous language (Australian Law Reform Commission, 2018; Schwartz \& Cunneen, 2009).

As has been well-documented by Blagg (2008), Cunneen (2001), White (2015) and others, the justice system continues to represent a form of colonial control over Aboriginal and Torres Strait Islander peoples. While this is clearly manifested by the hyperincarceration of indigenous peoples (White 2015), Eades (2008) has argued that control also extends to the routine language and communication practices of the justice system, which silence and exclude many indigenous witnesses from any kind of legitimate participation in their own legal matters. For Eades (2008), this is exhibited in the typical practices of a rigid "questionand-answer" format in examinations, which often conflicts with modes of communication used by many indigenous people who often value periods of silence and also use narrative responses to to clarify a situation (Eades, 2008). Common practices of courtroom discourse dictate how and when witnesses are allowed to speak, and what they are allowed to say (Eades, 2008). This has led to perceptions amongst some Aboriginal communities that courts simply do not want to hear what they have to say (Eades, 2000:168). Creating an ongoing need for decolonised approaches that seek to engage indigenous people and their communities in decisions about how to address issues of crime and the administration of justice (Blagg, 2008).

While Eades focused on how courtroom discourse effectively silences witnesses by controlling what they can say and when they can say it, control also extends to the language one is allowed to hear and speak, especially in the justice system. While Australia might 
no longer openly punish people for primarily speaking a language other than English, it continues to reinforce the hegemonic status of English by ensuring that access to major institutions is limited for speakers of minority languages ${ }^{1}$ (Coventry et al., 2015). In the justice system, there are two clear reasons for this: the first, as mentioned, is that there is a shortage of adequately trained legal interpreters in Australia, resulting by default in English monolingualism effectively being imposed on people, irrespective of their proficiency. The second is that English-speaking police and judges often hold discretionary power over when to use the available interpreters. Owing to this, even where interpreters are accessible, they may simply not be used on the belief that English-only communication will suffice. The exercising of this discretion becomes especially important if a person exhibits a superficial level of English-speaking ability, which may be sufficient for everyday conversations but not for the rigours of a police interview or a court proceeding (Cooke, 2002).

The long-standing failure to provide suitable numbers of professional legal interpreters in the justice system, coupled with the discretionary prerogative of officials to decide when (and when not) to use available interpreters, serves to regulate the language choices and preferences of people whose linguistic repertoires do not include English. When an interpreter is not available, a person is forced to act as an English monolingual speaker, irrespective of their relative ability to understand and speak fluently, or of their preference for using their first language to engage according to their own understanding and discretion (Eades, 2012). Conversely, as Cooke (1996) has argued, an interpreter can become a means of linguistic empowerment by allowing minority languages speakers greater access to language choice when giving evidence. It is significant that people's linguistic choices are shaped by the practical logistics of interpreter availability, as well as micro-level decisions which also reflect the broader systemic failure to provide adequate and quality legal interpreting services.

This chapter aims to demonstrate how under-provision of this service in the justice system, together with discretionary use of the available interpreters, emerges from a deep-seated ideological position that privileges and values English monolingualism (and, by extension, English monolingual speakers). Simultaneously, this position devalues and problematises linguistic diversity as a personal deficit, rather than a valuable resource (Ruiz, 1984). This ideological position is in force despite official policy statements claiming to support and celebrate an increasingly diverse Australia. Contemporary government rhetoric around valuing diversity, inclusiveness, tolerance, fairness and equity, often rings hollow in light of such actual practices in the justice system. In this way, the real practice of monolingualism 
continues to marginalise linguistic minorities, and to create an environment where miscarriages of justice can and do occur.

The following section of this chapter provides an analysis of the current state of legal interpreting in Australia, and the specific policies and practices of interpreter accreditation, illustrating ongoing shortcomings in the provision of properly trained and accredited legal interpreters in the justice system, despite repeated calls for improvement over the past 30 years. The third part offers an analysis of the discretionary use of interpreters by police during an interview, and by judges during court proceedings, demonstrating how preferring English-only communication simultaneously devalues the appropriate use of a different language. A key case study illustrates the consequences of poorly-exercised discretion in the case of a Pintupi-speaking young Aboriginal man, who suffered a substantial miscarriage of justice after being compelled to undergo multiple police interviews in English. The third part of this chapter discusses how linguistic stratification is embedded in both the law and the institutional discourse of the criminal justice system, a stratification that ensures that English monolingualism remains highly valued, and makes speakers of other languages appear deficient, vulnerable and even disabled in their capacity as communicators. The way the law frames the "right" to an interpreter, and the ways speakers of non-dominant languages are depicted in the legal process, are symptomatic of a system that sees linguistic diversity as a hindrance, a deficit and a "problem" which could be overcome if everyone simply spoke English. Therefore, while Australia claims to celebrate diversity, for at least one of its major institutions, the justice system, linguistic diversity remains an unwelcome and unwanted presence.

\section{Interpreter access and accreditation}

Despite repeated calls for improved access to highly qualified legal interpreters since 1988, there are still widespread inadequacies in the system that reveal an ongoing antipathy towards appropriate provision for llanguage diversity in the legal system. It is instructive that, in 1999, the year before the introduction of the Aboriginal Interpreter Service in the Northern Territory (10 April 2000), the then Chief Minister, Dennis Burke, expressed resistance to the idea by claiming that "providing Aborigines with interpreters was like giving a wheelchair to someone who should be walking" (Blundell, 2000). While access to interpreters in general has improved since the 1980s, there remain significant concerns over the both the quantity and quality of the services being provided. Particularly in legal settings, interpreters have to handle unique challenges. The system has not made interpreters readily available, or ensured that legal interpreting is of a suitably high standard, which continues to exclude minority language speakers from legitimate participation in the legal process. 
Focusing on the matter of competent interpreting, a national report into multicultural affairs in 1988 found that:

The provision of competent interpreters with a sound knowledge of the law and the legal system was identified by many of those consulted as a major means towards achieving genuine equality before the law ... Accessible, reliable interpreting is often critical to the exercise of justice.

(Australia: Advisory Council on Multicultural Affairs, 1988:2)

Although the final report of the above discussion paper dedicated very little space to interpreting, subsequent recommendations were put forward for a survey to be conducted by the Attorney-General's Department into interpreting requirements in legal contexts. Based on research and discussions that followed, a significant gap between law, policy and practice was revealed which in turn, directed attention to the urgent needs of legal interpreting (Ozolins, 1991:12). Although it has been over 30 years since the publication of the findings, the widespread provision of competent legal interpreting is yet to be achieved.

Reports into the need for specialist training for legal interpreters, in addition to research and reviews into the issues stemming from incompetent interpreting in the legal context, have been widely documented. An important review into appeals on grounds of poor interpreting, conducted by Hayes and Hale (2010), highlighted 119 appellate cases in Australia that led to the questioning of the interpreter's competence and/or qualifications. Moreover, the results of a survey conducted by Hale (2011) showed that, whilst judicial officers in general showed concern for the lack of quality in interpreting, $70 \%$ of the survey respondents (judicial officers) expressed their dissatisfaction with the current interpreting services. A number of studies and reviews in the context of court cases and police interviews have also documented examples of incompetent interpreting which have led to wrongful convictions and/or appeals (Nakane, 2009; Roberts-Smith, 2009).

Whilst issues of competence in interpreting in general can be dependent on the individual skills and training of interpreters, the main reason for the prevailing situation can be attributed to the systemic lack of recognition of the importance of specialist legal interpreting training and the lack of an accreditation/certification system that is designed to test the specific skills required for the level and demands of legal interpreting. Based on the findings of a study of interpreting services conducted in the Victorian County Court, Laster and Taylor (1994:14) state the following:

Many of the deficiencies blamed on individual interpreters, now and in the past, are the result of systemic problems, such as the lack of uniform education and testing to promote high levels of technical competence, and the failure to develop proper mechanisms for service delivery. Underlying these, of course, are inadequacies in the resources for legal interpreting services and levels of pay for interpreters. 
Former Western Australian Supreme Court Justice Len Roberts-Smith reviewed several cases of significance in which issues related to poor interpreting resulted in legal complexities (Roberts-Smith, 2009). He discussed these cases on the basis of three main factors, one of which relates to the services of "professional accredited" but untrained interpreters who do not possess the required high-level skills to perform as legal interpreters. The examples he provides support the argument that a generalist NAATI professional level accreditation alone, without specialist training, does not suffice for legal interpreting (Gamal, 2014; Hale, 2004; Hayes \& Hale, 2010; Lai \& Mulayim, 2013; Laster \& Taylor, 1994).

NAATI was initially set up in 1977 to professionalise interpreting and translation services to meet the language needs of new arrivals to Australia during migration in the 1970s, replacing the informal practices followed since the influx of post-war migrants in the late 1940s, in which family or friends of migrants were relied upon to act as ad hoc interpreters (Ozolins, 1991:17). Since then, NAATI has been the body responsible for setting the standards for translating and interpreting ( $\mathrm{T} \& \mathrm{I}$ ), testing of $\mathrm{T} \& \mathrm{I}$ accreditation, and approval of courses offered at tertiary and vocational training institutions. However, since its inception, NAATI has failed to raise the standards of interpreting and failed to recognise that the current credentialling system does not provide for the specialist skills needed for legal interpreting.

Until recently, NAATI's accreditation system had been awarding interpreter accreditations based on a generalised testing system with no specialist skills required other than candidates sitting a once-off interpreting test. Formal training in the area of interpreting was never compulsory but optional for those who wished to undertake such training through a NAATI-approved tertiary course, subject to the availability of the course in their language pair. The prerequisites for sitting the NAATI Professional-level test included the ability to speak two languages, an undergraduate degree in any field of study (but training in the fields of linguistics, languages, translation or related field was not required), or an interpreting accreditation at Paraprofessional level (for which an undergraduate degree is not needed).

Given that the Paraprofessional level test did not require any formal education at tertiary level, candidates with only secondary education, or perhaps with only primary education, were given the opportunity to attempt the test. A category called "Recognition" has also been awarded to candidates from rare and emerging languages in which there is a demand for interpreting services but a lack of examiner panels for such languages in which testing could be offered. In the Recognition category, candidates are not tested for their bilingual skills or interpreting skills. As mentioned previously, due to the generic structure of the NAATI tests, passing a NAATI test at any given level (Professional or Paraprofessional), or being awarded "Recognition" by NAATI, does not ensure competence in legal interpreting. 
Nevertheless, successful completion of the test meant interpreters were qualified to practise in courts and other legal settings (e.g. police interviews, tribunals).

Because compulsory training (as in other professions) was never a prerequisite for becoming an interpreter in Australia, those with formal training or qualifications are not given preference, nor do they receive remuneration commensurate with their formal qualifications. Hale (2007) has pointed out that if the legal system does not recognise appropriate payment for professional interpreting services, fees will not equate to the skills that are required. She also emphasises that until officers in the legal system working in collaboration with interpreters mandate higher standards and show support for an acceptable level of training and pay, nothing will change. The lack of recognition of highly skilled, formally trained interpreters by legal professionals has also resulted in a number of interpreters leaving the workforce and moving into other areas of more lucrative professional work. From the interpreters' standpoint, the central issue is their low status, represented by poor levels of pay; and this has had a serious bearing on the employment and retention of highly skilled, formally trained interpreters, thus in turn affecting the establishment of quality legal interpreting provisions (Laster \& Taylor, 1994). The cumulative result of these longstanding approaches has been a pool of interpreters not only underprepared and unsuited to interpreting in the highly specialised legal field, but a dilution of the amount of highly skilled and trained professionals capable of the demands of legal interpreting.

The repeated failure of Australian policy makers, institutions and interpreting organisations to promote greater numbers and higher standards of legally-trained interpreters perpetuates the linguistic exclusion of many from minority language backgrounds. While the provision of interpreters has often been idealised as a means of furthering substantive equality before the law, current policies and practices often render this goal as little more than symbolic rhetoric. As Angermeyer (2015) has suggested, the problems so often associated with access to, and use of, suitably qualified legal interpreters can be tied to broader underlying ideologies which work to demand monolingualism in English. For Angermeyer (2015), these structural and practical constraints mean that it would be better for minoritised language speakers to simply learn English if they wish to be treated fairly in their interactions with the justice system and forego their 'need' for an interpreter. In this way, the justice system further embeds linguistic inequality by privileging English monolingualism even in the face of the linguistically diverse backgrounds of many who find themselves in contact with police, courts and legal services. As the following sections will describe, not only can linguistic discrimination be seen at a policy level through the inadequate provision of services (Beacroft, 2017), but within micro-level discretionary practices of police and courts who act as linguistic gatekeepers (Heydon \& Mabasso, 2018) in determining when and under what circumstances a person will be allowed to converse in a language other 
than English through an interpreter. In the third part, we discuss how the discretionary use of interpreters can give rise to specific problems in practices and institutional discourse.

\section{Discretionary use of interpreters}

There is a clear need to provide greater numbers of highly skilled and legally trained interpreters in the justice system. However, it is also important to recognise that in Australia there is no automatic right to an interpreter for someone who does not speak English as a first language. Rather, access is dependent on one's ability (or more accurately, inability) to communicate in English. Legislative frameworks and common law precedent have largely established the use of interpreters as discretionary on the part of both courts and police. For example, Section 30 of Victoria's Evidence Act 2008 states this:

A witness may give evidence about a fact through an interpreter unless the witness can understand and speak the English language sufficiently to enable the witness to understand, and to make an adequate reply to, questions that may be put about the fact (emphasis added).

Similar provisions exist in most other state and territory jurisdictions. This framing of the "right" to an interpreter means that it is the courts that are tasked with deciding whether or not to use them in particular circumstances. While sometimes this decision may be obvious (such as for a monolingual non-English speaker), it becomes more challenging when a person exhibits some capacity to communicate in English, but may be more fluent in their first language (Cooke, 2002). While in theory this decision should be based on a formal assessment of English language proficiency, it can be subject to managerial concerns such as time and cost which are largely unrelated to language (Gibbons, 2003).

Like the courts, police also hold discretionary power regarding the use of interpreters during interviews with suspects and witnesses. While police are legally obliged to provide an interpreter, this only needs to be done in particular circumstances - specifically where a person is demonstrably unable to communicate adequately in English. ${ }^{2}$ Again, this assessment is ideally built on some kind of formal assessment of English proficiency (Cooke, 2002), but in reality can be based on superficial observation (Wakefield, Kebbell, Moston \& Westera, 2015).

At common law, the case of $R v$ Willie (1885) long ago established the importance of interpreters to procedural fairness when Justice Cooper of Queensland's Supreme Court discharged the case against four Aboriginal men facing murder charges because no interpreter could be found to assist (Goldflam, 2012). More recently, the High Court in

See Evidence Act 1995 (NSW) s.30 \& Division 3 of Law Enforcement (Powers and Responsibilities) Regulation 2005 (NSW); Police Powers and Responsibilities Act 2000 (Qld) s.512; Summary Offences Act 1953 (SA) s.83A; Criminal Law (Detention and Interrogation) Act 1995 (Tas) s.5. 
Re East $\mathcal{E}$ Ors; Ex Parte Nguyen (1998) reaffirmed this limited right when deciding whether the applicant had been denied procedural fairness because of the absence of an interpreter during the original trial. ${ }^{3}$ For the High Court, a trial is effectively conducted in the absence of the accused if they cannot understand the case against them, and are unable to articulate a defence. As such, a person's right to be "present" for their own trial, means not just physical presence, but linguistic presence also.

As Eades (2010) has articulated previously, however, interpreters can be viewed with suspicion, especially if a defendant speaks some English. In this regard, interpreters are not always seen as meeting a basic right, but as an advocate for a defendant or suspect (Eades, 2010). Moreover, the exercising of discretion around interpreters has often been based on flawed assumptions about English proficiency. Courts for example can sometimes rely on basic questions such as, "How long have you lived in Australia?" or "Where did you learn English?" to make this assessment. Not only do these questions not reflect the complexities of spoken language in court, they also assume, for example, that a person who has lived for a certain period in Australia will therefore speak English well enough to navigate the legal process. More significantly, however, is that assessments such as these only see English as worthy of consideration and so neglect any other capacities in one's first language. This means that assessments about the "need" for an interpreter can further reinforce the invisibility of minority languages (Wiley \& Lukes, 1996).

Given the discretionary nature of interpreter use, it is important to illustrate the implications for justice when this discretion is questionably exercised. The recent case of Gene Gibson is a stark example of how wrongful convictions can happen when interpreters are deemed unnecessary. In 2012, Gibson, a young Aboriginal man from the remote Pintupi-speaking community of Kiwirkurra, became a person of interest over the death of Josh Warneke in Broome, Western Australia. Gibson's first language was Pintupi, and his second Kukutja. He also had some English-speaking ability, and used it as a third language. The Pintupi community is known for the strength of its Aboriginal languages, which are often valued over the use of English in the community (The State of Western Australia v Gene Gibson, 2014). Gibson underwent two interviews with members of the Major Crime Squad (MCS); and, while the initial interview treated Gibson as a possible witness, he proceeded to make admissions which suggested some involvement in Warneke's death. Gibson was then treated as a suspect for subsequent interviews, during which he made similar admissions that resulted in his being charged with murder. 
During none of the interviews was an interpreter present owing to members of the MCS forming the opinion that, based on informal conversations with Gibson (in English) prior to the interviews, an interpreter was not necessary. It is not clear whether interviewing officers actually knew what Gibson's first language was, or that he spoke a first language other than English. Importantly, a Corruption and Crime Commission review into the investigation process found that the inquiries made into Gibson's English language proficiency were inadequate, and that police had failed to follow specific protocols about testing the suspect's English language proficiency (Corruption and Crime Commission, 2015). Indeed, local Broome police who were assisting the MCS investigation had recommended that an interpreter be used during the second and third interviews, given that English was clearly not Gibson's first language. The absence of an interpreter meant that the interviews were ruled inadmissible, and the admissions unreliable. As a result, the murder charge was downgraded to manslaughter, to which Gibson pleaded guilty.

In 2017, WA's Supreme Court of Appeal exonerated Gibson on the basis that the plea he entered into was not voluntarily made. In large part, this was because he did not have access to an interpreter during key meetings with his own lawyer, meaning that he was limited in his capacity to fully understand the case against him and his lawyer's advice, or to give proper instructions to the lawyer in response. Importantly, Gibson's lawyer had recognised that a Pintupi interpreter was likely to be important, but was not always available. As such, the absence of an interpreter at this stage was not so much based on a decision that one was not needed (such as the decision made by police). After spending five years in prison, Gibson was released and has now received a formal apology from the State, along with $\$ 1.3$ million compensation.

Of particular note within the Gibson case is the preferential regard for Gibson's third language (English) over his first, or even second, Aboriginal languages. While it would be easy to lay blame solely on the police, it is notable that legislative frameworks themselves can actually contribute to an environment where miscarriages of justice can and do arise. Not only do they require police to act as untrained linguists in making assessments about English proficiency (Cooke, 2002; Cotterill, 2000), but they also frame English monolingualism as the default preference for communication. From this perspective, it is unsurprising that interpreters can be underused, particularly if a person appears to speak English at a conversational level (Powell \& Bartholomew, 2003). As Eades (2015) has suggested, by constructing English as a social norm, the barring of access to interpreters can be justified based on untested assumptions that overestimate an individual's English proficiency. More importantly, however, it also reinforces the unwelcomeness of "other" languages in the legal process by rendering them invisible in favour of English monolingualism. 
Given that the decisions about interpreters are fundamentally tied to English, minority language speakers must either prove themselves to be sufficiently proficient in English to cope, or be so deficient as to "need" an interpreter (Angermeyer, 2014). It is notable that, in Gibson's case, the appeal court often referred to him as subject to "English language disabilities" (Gibson v The State of Western Australia, 2017:2) because he did not speak it as a first or second language. Gibson's Aboriginal languages, Pintupi and Kukutja, as well as his community's preferencing of Pintupi in everyday talk, had now come to be problematised as a contributor to a linguistic "disability", rather than a valuable commodity to be harnessed. The following discussion will further illustrate how linguistic diversity in the justice system frequently becomes viewed as a problem or deficit (sometimes overcome by enforcing English monolingualism), rather than as a valuable resource for promoting the legitimate participation of speakers of minority languages.

\section{Overcoming the "problem" of minority languages}

As Bourdieu and Thompson (1991) have argued, the ideology of a dominant language creates a standard by which people's linguistic practices are judged. In Bourdieu's terms, "when one language dominates the market, it becomes the norm against which ... other modes of expression, and with them the values of various competences, are defined" (Bourdieu, 1977:652). This becomes particularly true within social institutions (e.g. the legal system) which not only value particular language practices over others, but also construct these practices as "normal" or unmarked (Heller, 1995). This process of norm-creation is not a neutral one, but often serves the interests of particular groups to the exclusion of others. Language therefore becomes a central means through which symbolic domination is realised (Bourdieu, 1991). In Heller's (1995) words, "language norms are a key aspect of institutional norms, and reveal ideologies which legitimate institutional relations of power" (p. 373). This often serves to reinforce a monoglot standard, which denies and suppresses the actual practices of multilingualism and linguistic diversity (Silverstein, 1996), and also legitimises linguistic discrimination that uniquely affects minority language speakers (Phillipson, 1992). As such, not only do language ideologies in official settings serve the interests of those already wielding institutional authority, but they continue to reflect and legitimise broader social hierarchies that position minoritised language speakers as subordinate.

Moreover, the process of idealising and normalising English monolingualism gives rise to institutional discourses that operate to mark and assess the language practices of minoritised language speakers. This often results in a deficit orientation whereby certain people and groups are framed only in terms of their perceived linguistic failures. Within a legal context, Haviland (2003) suggests that legal ideologies about language depict English as the language of the "standard person" and English monolingualism as the repertoire 
of the "normal" language user. In comparison, non-English speakers are often marked as inadequate, and that "speaking English in part defines how a person shows him or herself not to be handicapped" (p. 746). In this regard, the use of an interpreter in the legal process is framed as a means of overcoming the perceived language "disabilities" experienced by somebody like Gene Gibson.

Because access to an interpreter is legally tied only to English, attitudes exhibited within the institutional discourse of Australian criminal justice systems are shaped by a "problem" orientation that depicts minority language speakers only as incapable communicators. As Ruiz (1984:16) argues, orientations towards broader language policy which problematise minority languages in this way also condition what is "thinkable" about linguistic diversity at a micro level.

In this sense, not only are minority languages not viewed as valuable, they can be seen only as a hindrance to both their speakers, and the institutions with which they interact (Harrison, 2007; Ruiz, 1984). Indeed, in order for someone to claim that they should be granted an interpreter (e.g. during a criminal appeal like that of Gene Gibson), adopting the status of a "deficient" English speaker is legally necessary, but not always successful. For example, this was exhibited in the following interaction that occurred in the case of Singh v The Queen (2014:13):

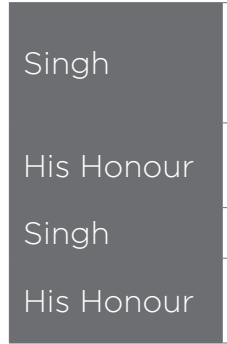

What I need, your Honour, I need interpreter because my English is not very well. I need a Punjabi interpreter or maybe Hindi, Indian and national language interpreter please, your Honour.

I don't accept that, Mr Singh, your English is sufficient for these purposes.

But I can't understand the difficult words, you know, some hard words. Well then we will avoid hard words. We'll be dealing with children so we won't be using hard words in any event.

Singh's proficiency in Punjabi is clearly of little importance in a court setting. For this appeal to succeed, he was required to position himself as an incompetent English speaker. It is also notable that, while the court summarily claimed that Singh would understand enough to get by, it then proceeded to infantilise him by saying "we won't be using hard words because children were also involved in the matter." Not only was Singh tasked with attempting to live up to a particular status of deficiency, but, in response, the court rendered his language preferences invisible because he had "sufficient" English language capability to cope, at least to a similar extent as a child. In this way, the means of overcoming the "problem" of another language was to suppress it entirely. 
In the case of DPP $v$ Natale (2018), an Italian man who was interviewed by police without an interpreter was described by the court in these terms:

Many of the answers of the accused are garbled or were expressed in barely understandable terms. Many answers give rise to concerns about his understanding of the situation he was in and the answers he was giving.

This language would be repeated later in the matter:

There is a real question about what the accused actually meant by various answers that he gave which were highly incriminating in relation to the alleged offending and other uncharged offending. His answers were often garbled and grandiose.

(p. 25)

However, while the court was required by law to illustrate Natale's inadequate use of English in order to rule that police should have provided an interpreter, it also reaffirmed that Natale's best language was clearly Italian (p. 39). Simply by establishing this as a relevant practical consideration in favour of interpreter use, discourses that focus solely on English "problems" can be resisted. By articulating and recognising Natale's preferred language, the court also recognised the value of allowing him to use it for the purposes of the interview. Indeed, the court went so far as to suggest that the police's failure to see it in this way constituted discrimination based on national origin. During the interview itself, Natale's efforts to assert a language preference and indicate discomfort in conversing in English were dismissed by interviewing officers. ${ }^{5}$ As such, while the court may have recognised Natale's language as a valuable asset for navigating the police interview, officers viewed it as a largely irrelevant concern.

While in Natale's case the court attempted to recognise the value of Natale's first language, the same could not be said about the case of The State of Western Australia v Cox (2008), Cox had been denied access to an interpreter during a police interview. His appeal involved a claim that this made the interviews unfair. In its ruling, the court recognised this as follows:

His preferred language is Kriol which is a dialect made up of a mixture of Aboriginal and English words. He also speaks English and it is not suggested, nor could it be concluded from the evidence, that his capacities in English were so limited as to necessitate an interpreter. However, it is clear from the evidence that his fluency in English is limited, and that he speaks a form of English sometimes described as Aboriginal-English, which may well give rise to issues as to the comprehension of his answers if the video record of interview is admitted into evidence.

They went on to say this:

The fact that an interpreter is not strictly necessary or essential does not mean that it is not desirable for an interpreter to be provided. There will be many cases - and this is one - in which the interests of justice will be advanced if an interpreter is present and available during police interview of a suspect and during any subsequent trial. (p. 4)

Natale had stated during the interview, "I don't know what you say in English. My language is -" before being cut off by officers (p. 8). 
While there is a recognition of Cox's preferred language, and even that an interpreter would have been beneficial, it did not result in a ruling that one should have been used by police. In this regard, the court believed that Cox did not present as suitably deficient to warrant access to an interpreter. His preferred language, Kriol, is largely erased as a concern which might justify the use of an interpreter, even if the use of an interpreter might have advanced the "interests of justice". Therefore, an interpreter is not viewed as "strictly necessary or essential" if one does not present as sufficiently inadequate in English. Indeed, the consideration of English alone not only supersedes any consideration of language preference, but even how justice might be better served by allowing a suspect to converse in a language he is most comfortable with an interpreter.

Clearly, having enough English to "get by" (or not being sufficiently deficient) can come to be viewed as inherently more valuable than greater proficiency in a minority language. In this way, the "problem" of linguistic diversity can be overcome simply by erasing it from practical consideration. For Gene Gibson, this meant being denied any opportunity to converse in Pintupi, because an informal conversation led police to believe an interpreter was unnecessary. For David Cox, even where the court acknowledged that justice would have been advanced had an interpreter been used, English-only communication was still preferred because he was not suitably inadequate in English. Upkar Singh was equated to a child when the court promised to "avoid hard words". In these ways, not only does the existence of a hegemonic language frame how language practices are judged (Bourdieu, 1977), but it can also work to render minority languages virtually invisible in official settings (Bourdieu \& Thompson, 1991).

\section{Conclusion}

The serious shortage of professional interpreters with competence in legal matters, both in indigenous languages and non-indigenous non-English languages, is by now well established, having been the subject of criticism and review for some 30 years. It is also indisputable that use of the available interpreters is subject to the discretion of police during interviews and and judges during court proceedings. These circumstances indicate that linguistic diversity represents an unwelcome and unwanted presence in the justice system, despite Australia's wider claims to celebrate diversity as a valuable part of contemporary Australian society.

The declaration of Chief Minister Dennis Burke in 1999, that providing interpreters was akin to giving a wheelchair to someone who should be walking (Blundell, 2000), is still represented in similar sentiments towards linguistic diversity in the policies and practices of Australian criminal justice systems. The expectation of linguistic unification, which the ideology of a state language demands, has the practical consequence of poorly equipped and 
understaffed interpreter services, and the problematic exercising of discretion around the use of available interpreters. Further to this, the ideology of an "official" language gives rise to an institutional discourse which marks people from linguistically diverse backgrounds as personally deficient because their value as communicators is tied only to English, and renders any capabilities in another language invisible.

Ultimately, this means that the use of interpreters in legal affairs, and by extension the use of minority languages, can still be viewed as a last resort and only of relevance in circumstances where English-only communication is virtually impossible. This privileging of English monolingualism will invariably mean the continued exclusion of those who do not primarily speak the dominant language; and, in the justice system at least, this will reinforce a social hierarchy that subordinates and stigmatises the language practices of indigenous and ethnic minority peoples.

\section{References}

\section{General}

Angermeyer, P.S. 2014. Monolingual ideologies and multilingual practices in small claims court: The case of Spanish-speaking arbitrators. International Journal of Multilingualism, 11(4):430-448.

Angermeyer, P.S. 2015. Speak English or what? Codeswitching and interpreter use in New York City Courts. New York: Oxford University Press.

Beacroft, L. 2017. Indigenous language and language rights in Australia after the Mabo (No 2) decision: A poor report card. James Cook University Law Review, 19(23):113-134.

Berk-Seligson, S. 1990. The bilingual courtroom: Court interpreters in the judicial process. Chicago: University of Chicago Press.

Bianco, J.L. 1987. National policy on languages. Canberra: Australian Government Publishing Service.

Blagg, H. 2008. Crime, aboriginality and the decolonisation of justice. Annandale NSW: Hawkins Press.

Blundell, H. 2000. A long fight for a basic human right. Alternative Law Journal, 25(5):219-223. https://doi.org/10.1177\%2F1037969X0002500503

Bourdieu, P. 1977. The economics of linguistic exchanges. Social Science Information, 16(6):645-668.

Bourdieu, P. \& Thompson, J.B. 1991. Language and symbolic power. Cambridge: Polity.

Chik, A. \& Benson, P. 2018. Council wants "English First" policy on shop signs - What does it mean for multicultural Australia? https://theconversation.com/council-wantsenglish-first-policy-on-shop-signs-what-does-it-mean-for-multicultural-australia-95777 [Retrieved 5 May 2019].

Cooke, M. 1996. A different story: Narrative versus "question and answer" in Aboriginal evidence. International Journal of Speech Language and the Law, 3(2):273-288

Cooke, M. 2002. Indigenous interpreting issues for courts. Carlton VIC: Australian Institute of Judicial Administration.

Cotterill, J. 2000. Reading the rights: A cautionary tale of comprehension and comprehensibility. Forensic Linguistics, 7(1):4-25. 
Coventry, G.; Dawes, G.; Moston, S. \& Palmer, D. 2015. Sudanese refugees' experiences with the Queensland criminal justice system: Report to the Criminology Research Advisory Council. Canberra ACT: Australian Institute of Criminology.

Cunneen, C. 2001. Conflict, politics and crime: Aboriginal communities and the police. Crows Nest NSW: Allen \& Unwin.

Eades, D. 2008. Courtroom talk and neocolonial control. New York: Mouton de Gruyter.

Eades, D. 2010. Sociolinguistics and the legal process. Bristol: Multilingual Matters.

Eades, D. 2012. The social consequences of language ideologies in courtroom crossexamination. Language in Society, 41(4):471-497.

Eades, D. 2015. Language varieties spoken by Aboriginal people in the Northern Territory today. Paper presented at the Northern Territory Supreme Court Language and the Law Conference, August 2015, Supreme Court, Darwin NT. http://www. supremecourt.nt.gov.au/conferences/documents/presenter-info/Diana\%20Eades.pdf [Retrieved 30 May 2018].

Gibbons, J. 2003. Forensic linguistics. An introduction to language in the justice system. Oxford: Blackwell Publishing.

Goldflam, R. 2012. Ngayulu nyurranya putu kulini: The legal right to an interpreter. Paper presented at the Northern Territory Language and the Law Conference, May 2012, Supreme Court NT.http://www.supremecourt.nt.gov.au/about/documents/r_goldflam_ ngayulu_nyurranya_putu_kulini.pdf [Retrieved 25 May 2018].

Hale, S. 2003. What does "to fully and faithfully interpret the evidence" mean? Paper presented at the Interpreters and Legal Professionals Working Together in Courts and Tribunals Conference, 21 March, University of New South Wales.

Hale, S. 2004. The discourse of court interpreting: Discourse practices of the law, the witness and the interpreter. Amsterdam: John Benjamins.

Hale, S. 2007. The challenges of court interpreting: Intricacies, responsibilities and ramifications. Alternative Law Journal, 32(4):198-202.

Hale, S. 2011. Interpreter policies, practices and protocols in Australian courts and tribunals. A national survey. Melbourne: Australasian Institute of Judicial Administration.

Harrison, G. 2007. Language as a problem, a right or a resource? A study of how bilingual practitioners see language policy being enacted in social work. Journal of Social Work, 7(1):71-92.

Haviland, J.B. 2003. Ideologies of Language: Some reflections on language and US Law. American Anthropologist, 105(4):764-774.

Hayes, A. \& Hale S. 2010. Appeals on incompetent interpreting. Journal of Judicial Administration, 20:119-130.

Heller, M. 1995. Language choice, social institutions, and symbolic domination. Language in Society, 24(3):373-405. https://doi.org/10.1017/S0047404500018807

Lai, M. \& Mulayim, S. 2013. Interpreter linguistic intervention in the strategies employed by police in investigative interviews. Police Practice and Research: An International Journal, 15(4):307-321. https://doi.org/10.1080/15614263.2013.809929

Laster, K. \& Taylor, V.L. 1994. Interpreters and the legal system. Sydney: Federation Press.

Marmion, D.; Obata, K. \& Troy, J. 2014. Community, identity, wellbeing: The report of the Second National Indigenous Languages Survey. Canberra ACT: Australian Institute of Aboriginal and Torres Strait Islander Studies.

Nakane, I. 2009. The myth of an "invisible mediator": An Australian case study of EnglishJapanese police interpreting. Journal of Multidisciplinary International Studies, 6(1). https://epress.lib.uts.edu.au/journals/index.php/portal/article/view/825 [Retrieved 2 November 2018].

Ozolins, U. 1991. Interpreting translating and language policy. East Melbourne: National Languages Institute of Australia. 
Phillipson, R. 1992. Linguistic imperialism. New York: Routledge.

Piller, I. 2016. Linguistic diversity and social justice: An introduction to applied sociolinguistics. Oxford: Oxford University Press.

Powell, M.B. \& Bartholomew, T. 2003. Interviewing and assessing clients from different cultural backgrounds: Guidelines for all forensic professionals. In: D. Carson \& R. Bull (eds.), Handbook of psychology in legal contexts. Chichester, West Sussex: Wiley. p. 65.

Roberts-Smith, L. 2009. Forensic interpreting: Trial and error. In: S. Hale \& U. Ozolins (eds.), Critical Link 5. Quality in interpreting: A shared responsibility. Amsterdam: John Benjamins. pp. 13-35.

Ruiz, R. 1984. Orientations in language planning. NABE Journal, 8(2):15-34.

Schwartz, M. \& Cunneen, C. 2009. Working cheaper, working harder: Inequity in funding for Aboriginal and Torres Strait Islander legal services. Indigenous Law Bulletin, 7(10):19-22.

Silverstein, M. 1996. Monoglot "standard" in America: Standardization and metaphors of linguistic hegemony. In: D. Brenneis \& R.K.S. Macaulay (eds.), The matrix of language: Contemporary linguistic anthropology. New York: Routledge.

Wakefield, S.J.; Kebbell, M.R.; Moston, S. \& Westera, N.J. 2014. Perceptions and profiles of interviews with interpreters: A police survey. Australian and New Zealand Journal of Criminology, 48(1):72. https://doi.org/10.1177\%2F0004865814524583

White, R. 2015. Indigenous young people and hyperincarceration in Australia. Youth Justice, 15(3):256-270.

Wiley, T.G. \& Lukes, M. 1996. English-only and Standard English ideologies in the U.S. TESOL Quarterly, 30(3):511-535.

\section{Official reports and publications}

Access \& Equity Inquiry Panel. 2012. Access and equity for a multicultural Australia: Inquiry into the responsiveness of Australian Government Services to Australia's culturally and linguistically diverse population. Canberra ACT: Commonwealth of Australia.

Advisory Council on Multicultural Affairs. 1988. Towards a national agenda for a multicultural Australia: A discussion paper. Canberra: Australian Government Public Service (AGPS).

Attorney-General's Department. 1991. Access to interpreters in the Australian legal system: Report. Canberra: Australian Government Public Service (AGPS).

Australian Bureau of Statistics. 2016a. Media release: Census reveals a fast changing, culturally diverse nation. http://www.abs.gov.au/ausstats/abs@.nsf/lookup/Media\%20 Release3 [Retrieved 14 March 2018].

Australian Bureau of Statistics. 2016b. National Aboriginal and Torres Strait Is/ander social survey: Language and culture. http://www.abs.gov.au/ausstats/abs@.nsf/Lookup/ by\%2OSubject/4714.0 2014-15 Main\%2OFeatures Language\%2Oand\%2Oculture 3 [Retrieved 14 March 2018].

Australian Bureau of Statistics. 2017a. Aboriginal and Torres Strait Islander prisoner characteristics. http://www.abs.gov.au/ausstats/abs@.nsf/Lookup/by\%20 Subject/4517.0 2017 Main\%2OFeatures Aboriginal\%2Oand\%20Torres\%20Strait\%20 Islander\%20prisoner\%20characteristics 5 [Retrieved 15 March 2018].

Australian Bureau of Statistics. 2017b. Aboriginal and Torres Strait Islander prisoner characteristics: Northern Territory. http://www.abs.gov.au/ausstats/abs@.nsf/ Lookup/by\%2OSubject/4517.0 2017 Main\%2OFeatures Northern\%2OTerritory 24 [Retrieved 15 March 2018].

Australian Bureau of Statistics. 2017c. Aboriginal and Torres Strait Islander prisoner characteristics: Western Australia. http://www.abs.gov.au/ausstats/abs@.nsf/ Lookup/by\%20Subject/4517.0 2017 Main\%2OFeatures Western\%2OAustralia 22 [Retrieved 16 March 2018]. 
Australian Department of Social Services. 2017. Multicultural Australia: United, strong, successful. Australia's multicultural statement. https://www.homeaffairs.gov.au/mca/ Statements/english-multicultural-statement.pdf [Retrieved 28 March 2018].

Australian Law Reform Commission. 1992. Multiculturalism and the law. Sydney NSW: Commonwealth of Australia.

Australian Law Reform Commission. 2017. Pathways to justice: An inquiry into the incarceration rate of Aboriginal and Torres Strait Islander peoples. Canberra, ACT: Commonwealth of Australia. https://www.alrc.gov.au/sites/default/files/pdfs/ publications/final_report_133_amended1.pdf [Retrieved 25 February 2018].

Corruption and Crime Commission. 2015. Report on Operation Aviemore: Major crime squad investigation into the unlawful killing of Mr Joshua Warneke. Perth WA: Corruption and Crime Commission.

Human Rights and Equal Opportunity Commission. 1997. Bringing them home: National inquiry into the separation of Aboriginal and Torres Strait Islander children from their families. Canberra ACT: Commonwealth of Australia.

National Accreditation Authority for Translators and Interpreters. 2016. Annual Report 2015-2016. Canberra ACT: NAATI.

\section{Legislation}

Criminal Law (Detention and Interrogation) Act 1995 (Tas).

Evidence Act 1929 (SA).

Evidence Act 1995 (NSW).

Evidence Act 1997 (Qld).

Evidence Act 2001 (Tas).

Evidence Act 2008 (Vic).

Evidence (National Uniform Legislation) Act 2016 (NT).

Law Enforcement (Powers and Responsibilities) Regulation 2005 (NSW).

Police Powers and Responsibilities Act 2000 (QId).

Summary Offences Act 1953 (SA).

\section{Cases}

DPP V Natale (2018) VSC 339.

Gene Gibson v The State of Western Australia (2017) WASCA 141.

$R \vee$ Willie (1885) 7 QLJ (NC) 108.

Re East \& Ors; Ex parte Nguyen (1998) HCA 73.

Singh $v$ The Queen (2014) NTCCA 16.

The State of Western Australia v Cox (2008) WASC 287.

The State of Western Australia v Gene Gibson (2014) WASC 240. 